\title{
Effect of Soil Saturation Duration and Soil Water Content on Root Rot of Maize Caused by Pythium arrhenomanes
}

\author{
Y. Yanar, Graduate Student, Department of Plant Pathology; P. E. Lipps, Professor, Department of Plant Pathology, \\ The Ohio State University, The Ohio Agricultural Research and Development Center, Wooster 44691; and I. W. \\ Deep, Professor, Department of Plant Pathology, The Ohio State University, Columbus 43210
}

\begin{abstract}
Yanar, Y., Lipps, P. E., and Deep, I. W. 1997. Effect of soil saturation duration and soil water content on root rot of maize caused by Pythium arrhenomanes. Plant Dis. 81:475-480.

Three aggressive isolates of $P$. arrhenomanes (201-25, 7E, and 5E) were used to evaluate the effect of soil saturation duration and soil water content on maize root rot. Maize seedlings grown in infested and noninfested soil:sand mixtures were subjected to saturation durations of 0 , 6, 12, 24, or $40 \mathrm{~h}$. Four silty-clay loam soil:sand mixtures (100:0, 80:20, 50:50, and 0:100) were used to evaluate the effect of soil water content on disease development. Matric water potential was maintained at $-1 \mathrm{~J} / \mathrm{kg}$ during the experiment except for the saturation period. Multiple regression analysis was used to evaluate the effect of saturation duration and soil water content on root and shoot dry weight. Negative slope values were obtained for increasing saturation duration and reduced water content (increased proportion of sand to soil). Intercepts of regression lines for shoot and root dry weights were lower for the infested soil:sand treatments than the noninfested treatments. These results indicated that growth of maize plants was negatively affected by increased flooding duration, lower soil water content, and presence of the pathogen. Growth of maize was significantly $(P=0.05)$ less in the presence of the pathogen than in noninoculated control treatments at each soil water content and flooding duration.
\end{abstract}

Pythium arrhenomanes Drechsler is a common pathogen of maize (Zea mays L.), particularly in soils that retain water $(9,17,24,29,30)$. Research to determine the significance of Pythium root rot in the production of maize has been hampered by the inability to isolate $P$. arrhenomanes directly from soil and root tissues throughout the growing season. $P$. arrhenomanes could be isolated from maize root tissues for only a few days after rain events that saturated soil (7). Isolation of $P$. graminicola from maize roots also was inconsistent throughout the growing season (14). The association of high soil moisture and the ability to isolate Pythium spp. after rain events suggests a relationship between periods of soil saturation and the level of Pythium root rot.

Few studies have determined the relationship between soil water and severity of diseases caused by Pythium spp. However, as early as 1919 , interactions of soil water

Corresponding author: P. E. Lipps

E-mail: lipps.1@osu.edu

Portion of a thesis submitted by the first author in partial fulfillment of the requirements for the M.S. degree, The Ohio State University.

Accepted for publication 10 February 1997.

Publication no. D-1997-0313-05R

(C) 1997 The American Phytopathological Society and disease severity were observed (18). In general, near-saturated soil conditions increased the incidence of root rot caused by various Pythium spp. $(4,6,11,12)$. High soil moisture directly favors Pythium spp. by providing a continuous water film necessary for zoospore production and motility $(20,33,34)$. In addition, high soil water may indirectly favor infection and colonization of the host tissues by the fungus by decreasing host vigor and increasing the release of host exudates that may stimulate germination of dormant propagules $(1,4,33)$. The effect of soil water on zoospore release by Phytophthora spp. is well documented (13,15,22,28,32). Duniway $(10,11)$ demonstrated that protracted periods of saturated conditions favor zoospore formation, release, dispersal, and attachment to root surfaces. Soil pore size distribution, as it relates to soil texture, limits the movement of zoospores by determining the number of pores large enough to accommodate motile spores $(10,28)$.

The duration and number of periods of soil saturation increases the level of root rot incited by several Phytophthora spp. $(3,5,19,23,32,36,37)$. For example, Bowers et al. (3) demonstrated that when soil infested with oospores of Phytophthora capsici was held at constant $-2.5 \mathrm{~J} / \mathrm{kg}$ matric potential for 37 to 40 days, a low level of disease occurred. In contrast, when the infested soil was periodically saturated, $20 \%$ of the pepper plants died after a single 24-h saturation period. When the saturation period was repeated two and three times,
53 and $100 \%$ of the plants died, respectively. Similarly, Wilcox et al. $(36,37)$ reported that Phytophthora root and crown rot of cherry trees occurred most frequently in orchards with poorly drained or periodically saturated soil and that longer periods of saturation ( 24 to $48 \mathrm{~h}$ ) increased disease incidence.

Reduced tillage is an increasingly popular method for managing soil and crop residues in Ohio (2). However, in poorlydrained clay soils, lower yields were obtained with reduced tillage and continuous maize than with fall plowing and a maizesoybean rotation $(8,35)$. These results suggest that reduced yield may have been associated with greater water-retaining properties of soil and the use of reduced tillage or continuous corn $(8,13,30)$. Our study was undertaken to determine the influence of soil saturation duration and soil water content on root rot of young maize plants caused by $P$. arrhenomanes.

\section{MATERIALS AND METHODS}

Media. The Pythium-selective PY-medium developed by Schmitthenner (31) was used throughout this study. The medium contained $2.5 \mathrm{~g}$ sucrose, $0.27 \mathrm{~g}$ asparagine, $0.15 \mathrm{~g} \mathrm{KH}_{2} \mathrm{PO}_{4}, 0.15 \mathrm{~g} \mathrm{~K}_{2} \mathrm{HPO}_{4}$, $0.10 \mathrm{~g} \mathrm{MgSO}_{4} \cdot 7 \mathrm{H}_{2} \mathrm{O}, 0.08 \mathrm{~g} \mathrm{CaCl}_{2}, 0.01 \mathrm{~g}$ cholesterol, $0.01 \mathrm{~g}$ ascorbic acid, $0.002 \mathrm{~g}$ thiamine, $0.01 \mathrm{~g}$ chloroamphenicol, 0.027 $\mathrm{g}$ pentachloronitrobenzene (PCNB), $0.02 \mathrm{~g}$ benomyl, $0.10 \mathrm{~g}$ neomycin sulfate, $19 \mathrm{~g}$ bacto agar, and 1,000 $\mathrm{ml}$ water. The antibiotics were added aseptically after the medium was autoclaved. The medium was modified for maintaining $P$. arrhenomanes cultures by leaving out the fungicides, PCNB, and benomyl.

Soil. Hoytville silty-clay loam (Mollic ochraqualf, sand $21 \%$, silt $39 \%$, clay $40 \%$ ) obtained from rotation-tillage plots located at the Ohio Agricultural Research and Development Center Northwest Branch (OARDC-NW Branch) near Hoytville was used in all experiments $(21,35)$.

Inoculum. A soil-potato medium was prepared by mixing $400 \mathrm{~g}$ Hoytville siltyclay loam, $100 \mathrm{~g}$ river sand, and $50 \mathrm{~g}$ chopped potato. The ingredients were mixed by hand with enough water to obtain a friable, moist medium. The $550 \mathrm{~g}$ of medium was placed in a one liter flask closed with a cotton plug, covered with aluminum foil, and then autoclaved on two consecutive days at $121^{\circ} \mathrm{C}$ for $90 \mathrm{~min}$ each 
day. Sterile distilled water was added to maintain adequate moisture for fungal growth as needed. P. arrhenomanes isolates were grown on modified PY-medium for 3 days in 9-cm-diameter petri dishes, then half the volume of a dish was transferred to each flask of soil-potato medium. After inoculation, flasks were maintained at 22 to $25^{\circ} \mathrm{C}$ for 6 days and periodically shaken by hand. Microscopic examination indicated that inoculum consisted mostly of mycelium and sporangia, but the proportion of sporangia capable of producing zoospores was unknown.

Aggressiveness tests. Fifteen $P$. arrhenomanes isolates previously obtained from maize roots collected from field plots at the OARDC-NW Branch were tested for aggressiveness on maize. Tests were conducted three times with four replications using a completely randomized-block, factorial design. The factors were isolate,

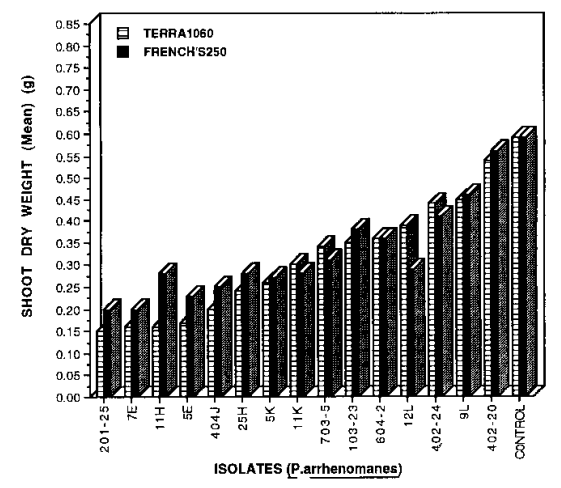

Fig. 1. Effect of Pythium arrhenomanes isolate on shoot dry weight of maize hybrid Terra 1060 and French's 250 thirty days after planting in infested Hoytville silty-clay loam or a 50:50 (wt/wt) mixture of Hoytville silty-clay loam: river sand. Least significant difference $=0.04 \mathrm{~g}$ $(P=0.05)$

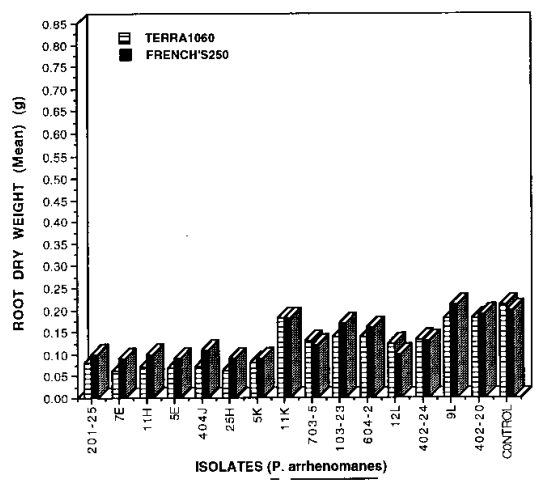

Fig. 2. Effect of Pythium arrhenomanes isolate on root dry weight of maize hybrid Terra 1060 and French's 250 thirty days after planting in infested Hoytville silty-clay loam or a 50:50 (wt/wt) mixture of Hoytville silty-clay loam:river sand. Least significant difference $=$ $0.02 \mathrm{~g}(P=0.05)$. soil mixture, and maize hybrid. The two soil mixtures were Hoytville silty-clay loam and a 50:50 (wt/wt) mixture of Hoytville silty-clay loam and river sand. The two soil mixtures were used to obtain different water contents in the soil matrix. The soil mixtures were sterilized by autoclaving at $121^{\circ} \mathrm{C}$ for $24 \mathrm{~h}$ prior to use. The two hybrids were Terra 1060 and French's 250. Soil-potato inoculum $(550 \mathrm{~g})$ was mixed with sterile soil or the soil:sand mixture $(5080 \mathrm{~g})$ and divided equally into eight $11.5-\mathrm{cm}$-diameter plastic pots. Noninfested soil-potato medium was mixed with sterile soil or the soil:sand mixture for control treatments. Four seeds were planted in each pot (four pots/isolate/soil/ hybrid). Pots were watered to saturation daily and $50 \mathrm{ml}$ of nutrient solution was added every 2 days. The nutrient solution was prepared by mixing a stock solution of a commercial 20-20-20 fertilizer (Peters Professional, Scotts-Sierra Horticultural Products Co., Marysville, $\mathrm{OH})$ to obtain 400 ppm N-P-K. Plants were maintained in a greenhouse in sunlight with an air temperature ranging from 22 to $25^{\circ} \mathrm{C}$. Thirty days after planting, shoots were cut at the soil surface and placed in paper bags. Roots were washed free of soil under running tap water and examined for root rot. Several small discolored root pieces were selected for reisolation of the fungus on PY-medium and the remainder placed in paper bags. Plant tissues were dried in an oven at $51^{\circ} \mathrm{C}$ until no further weight was lost, and dry weights of roots and shoots recorded.

Effect of saturation duration and soil water content. Three aggressive isolates (7E, 5E, and 201-25) were chosen to evaluate the effect of saturation duration and soil water content on severity of maize root rot using the hybrid Terra 1060. The experiment was conducted three times with four replications using a split-split plot design in which the whole plot was isolate, subplot was soil:sand mixture, and subsubplot was saturation duration. In order to obtain soils of different water content based on soil texture, Hoytville silty-clay loam and river sand were mixed on a dry weight basis to obtain four soil:sand mixtures (100:0, 80:20, 50:50, and 0:100). After mixing, soil:sand mixtures were autoclaved at $121^{\circ} \mathrm{C}$ for $24 \mathrm{hr}$. Five periods of saturation duration $(0,6,12,24$, and 40 h) were tested.

Soil-potato inoculum was mixed with each soil:sand mixture and placed into 14cm-diameter Styrofoam cups. Each cup contained $55 \mathrm{~g}$ of soil-potato inoculum and $1000 \mathrm{~g}$ of a soil:sand mixture, based on dry weight. Noninfested soil-potato medium mixed with each soil:sand mixture served as the control treatments. Four seeds were planted in each cup, then cups were arranged on the greenhouse bench and maintained at 22 to $25^{\circ} \mathrm{C}$ in sunlight. Four days after planting, cups with seedlings were placed in 14-cm-diameter, 3-cm-deep plastic saucers. The height of water in the saucers was maintained at $10 \mathrm{~cm}$ below the soil surface in each cup so that all soils would be maintained at a matric water potential above $-1 \mathrm{~J} / \mathrm{kg}$. Water was added to saucers each day to maintain this specific water level. Every other day, $50 \mathrm{ml}$ of a 400 ppm N-P-K nutrient solution, prepared as described earlier, was added to the soil surface of each cup. Ten days after planting, pots were placed in large containers so water could be added to bring the water surface level with the soil surface in each cup. This level was maintained until cups were removed at the end of each saturation duration period. Each saturation treatment was repeated 10 days later.

Table 1. Analysis of variance for main effects of Pythium arrhenomanes isolates (isolate), water content in soil (water), saturation duration (saturation), and interaction of these factors on shoot and root dry weights of maize plants grown in the greenhouse

\begin{tabular}{lccc}
\hline & & Shoot weight & Root weight \\
\cline { 3 - 4 } Source of variation & $\mathbf{d f}^{\mathbf{a}}$ & $\mathbf{M S}^{\mathbf{b}}$ & $\mathbf{M S}$ \\
\hline Experiment & 2 & $57.57^{* * * \mathbf{c}}$ & $25.77^{* * *}$ \\
Experimental error & 9 & 0.246 & 0.063 \\
Isolate & 3 & $92.10^{* * * *}$ & $13.56^{* * * *}$ \\
Isolate error & 27 & $0.046^{*}$ & $0.013^{* * *}$ \\
Water & 3 & $22.11^{* * *}$ & $3.27^{* * *}$ \\
Water error & 27 & 0.053 & $0.011^{*}$ \\
Isolate* water & 9 & $3.53^{* * *}$ & $0.49^{* * *}$ \\
Isolate* water error & 81 & $0.055^{* * *}$ & $0.022^{* * *}$ \\
Saturation & 4 & $9.30^{* * *}$ & $2.76^{* * *}$ \\
Saturation* isolate & 12 & $0.391^{* * *}$ & $0.063^{* * *}$ \\
Saturation* water & 12 & $0.09^{* * *}$ & $0.02^{* * *}$ \\
Saturation* isolate* water & 36 & $0.042^{* *}$ & $0.01^{*}$ \\
Error & 396 & 0.025 & 0.006 \\
$R^{2}$ & & 0.98 & 0.98 \\
\hline
\end{tabular}

${ }^{\mathrm{a}} \mathrm{df}=$ degrees of freedom.

${ }^{\mathrm{b}} \mathrm{MS}=$ mean squares were obtained from analysis of variance table.

${ }^{c}$ Three asterisks indicate significance at $P=0.0001$, two asterisks indicate significance at $P=0.001$, and one asterisk indicates significance at $P=0.05$. 
Thirty-five days after planting, plants were cut at the soil surface and tops placed into paper bags. Roots were washed free of soil under running tap water and placed into paper bags. All tissues were dried in an oven at $51^{\circ} \mathrm{C}$ until no further weight was lost, and then dry weights were recorded.

Statistical analyses. Shoot and root dry weight data (an observation was the mean of four plants per pot) were analyzed by analysis of variance (ANOVA) procedures (SAS Institute, Cary, NC). Means were compared using Fisher's least significant difference. Relationships among saturation durations, soil water content, and plant shoot and root dry weights were examined by regression analysis using the general linear models (GLM) procedures of SAS. The multiple regression equation used was: $Y=b_{\mathrm{o}}+b_{1}(\mathrm{FD})+b_{2}(\mathrm{PS})$ in which $Y$ was shoot or root dry weight (dependent variable), FD was flooding duration, PS was percentage of sand in soil:sand mixtures, and $b_{0}, b_{1}$, and $b_{2}$ were parameters. Simple correlations were calculated to determine the relationships between shoot and root dry weights.

\section{RESULTS}

Isolate aggressiveness test. The experiment was conducted three times, each time during a different month of the year. Actual mean values for shoot and root dry weight for isolates were different for each experiment, but the rank order of isolate means did not change appreciably across experiments (data not presented). Combined analysis of the three experiments indicated that the main effect of the two soil:sand mixtures was not significant $(P=$ 0.05 ) and the interactions of soil:sand mixture by isolate, hybrid by soil:sand mixture, and hybrid by isolate by soil:sand mixture also were not significant for shoot and root dry weight.

The main effect of isolate and the hybrid by isolate interaction were significant for both shoot and root dry weight $(P<0.05)$. Thus, data for the two hybrids are presented separately (Figs. 1 and 2). The significant interaction was due to a wide range in reduction (5 to $75 \%$ ) of plant shoot dry weight caused by the 15 isolates tested, with the more aggressive isolates causing greater reduction in shoot dry weight on Terra 1060 than on French's 250 compared to less aggressive isolates (Fig. 1). Reduction in root dry weight followed a similar trend (0 to $72 \%$ reduction) (Fig. 2). All isolations from discolored root tissues collected from test plants yielded cultures of $P$. arrhenomanes. Highly aggressive isolates 201-25, 7E, and 5E were selected for use in additional tests.

Influence of saturation duration and soil water content. The experiment was conducted three times, each time during a different month of the year. Therefore, the experiment was analyzed as replicated over time (Table 1). The main effect of experiment was significant $(P=0.0001)$, indicating that environmental conditions affected growth of plants differently during repetitions of the experiment. The main effect of isolate also was significant $(P=$ $0.0001)$. For most treatments, isolate 20125 caused less reduction in shoot and root dry weight than isolates $5 \mathrm{E}$ or $7 \mathrm{E}$ (Figs. 3 and 4). All two-way and the three-way interactions were significant $(P=0.01)$ for shoot and root dry weight (Table 1).

Negative slope values were obtained for the relationships between soil saturation duration and soil water content for shoot
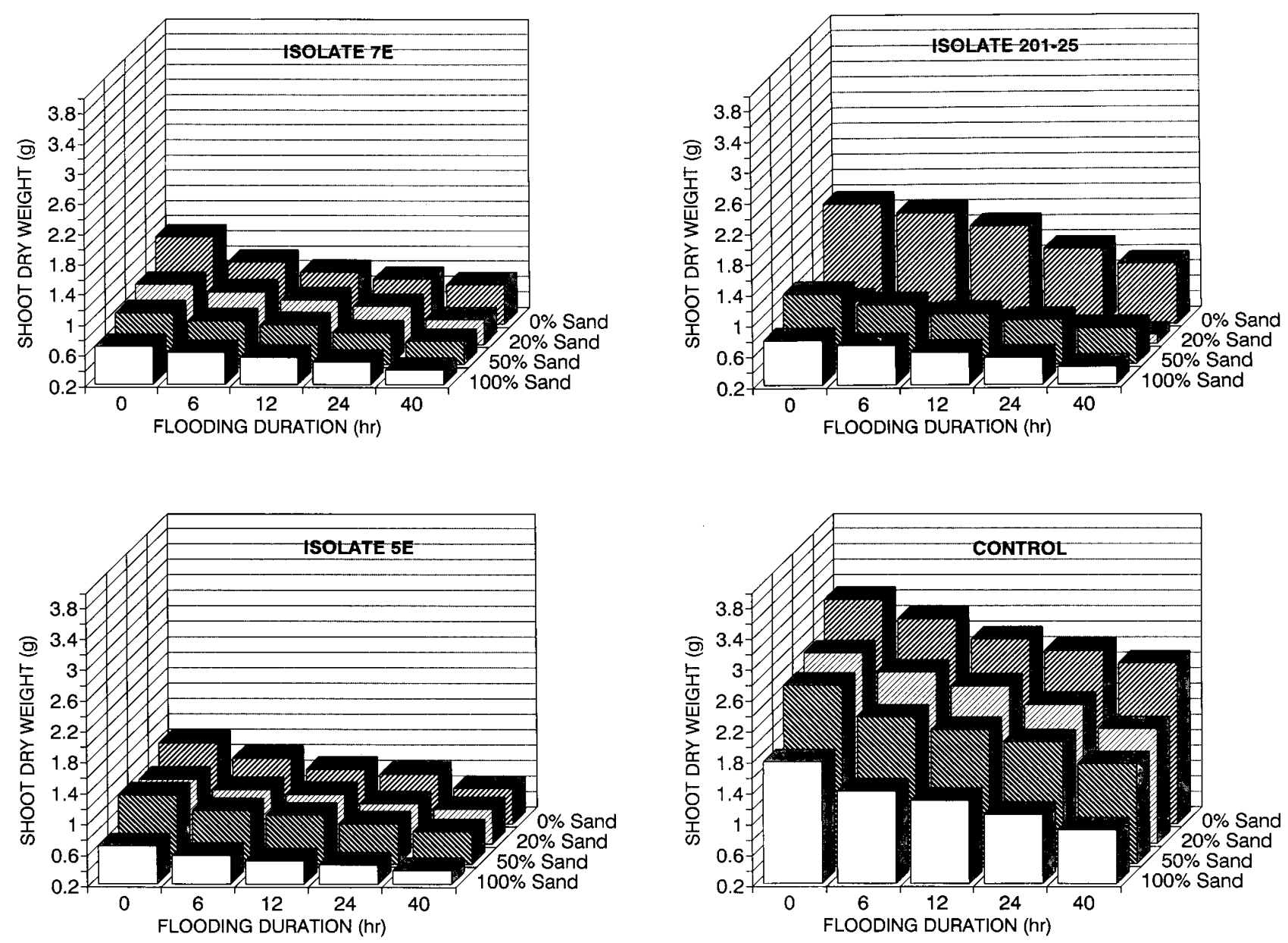

Fig. 3. Effect of soil saturation duration and soil water content (percent river sand in Hoytville silty-clay loam) on shoot dry weight of maize hybrid Terra 1060 infested with three isolates of Pythium arrhenomanes (7E, 201-25, and 5E) and a noninfested control 35 days after planting. Least significant difference $=0.13 \mathrm{~g}(P=0.05)$. 

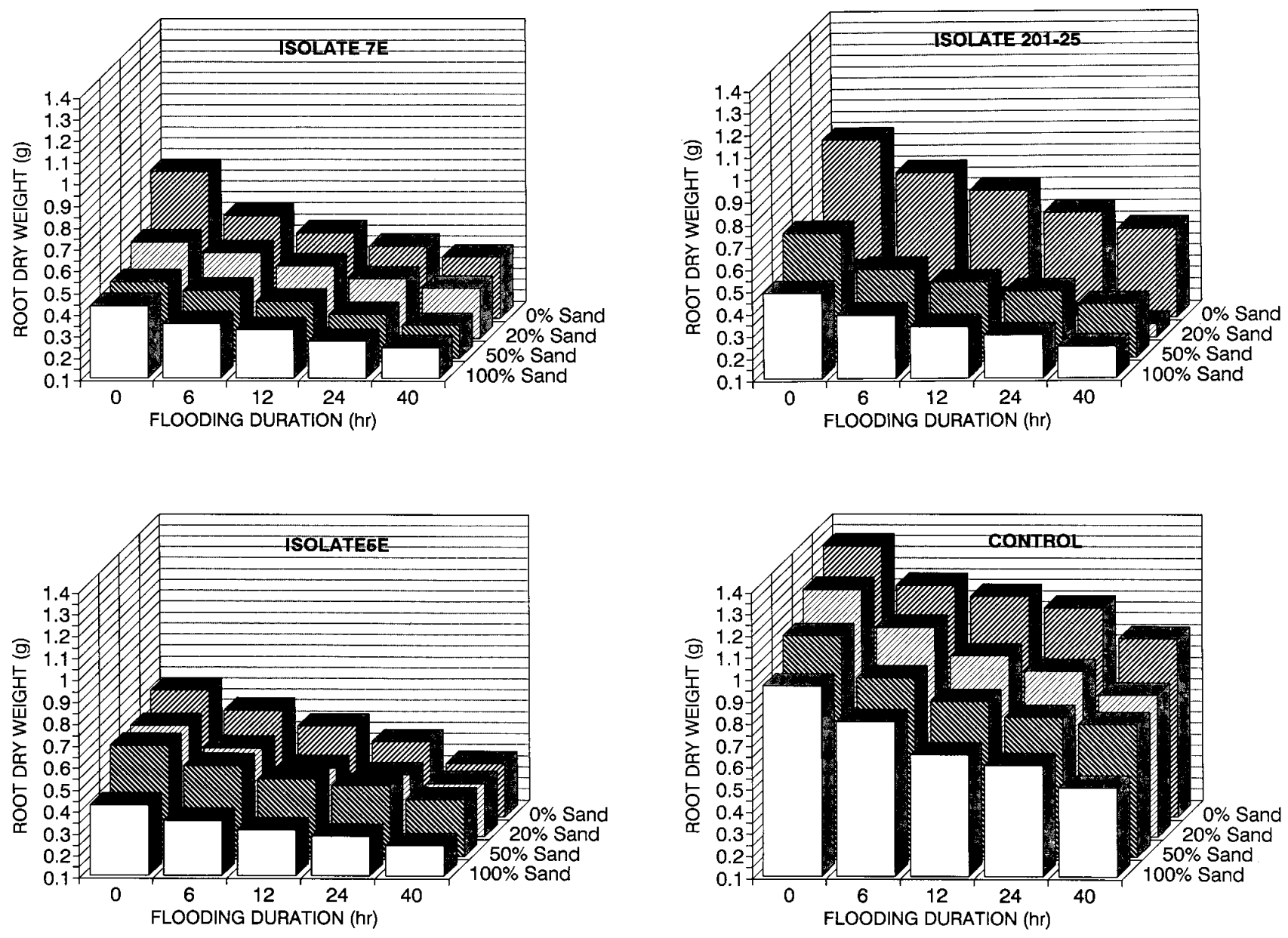

Fig. 4. Effect of soil saturation duration and soil water content (percent river sand in Hoytville silty-clay loam) on root dry weight of maize hybrid Terra 1060 infested with three isolates of Pythium arrhenomanes (7E, 210-25, and 5E) and a noninfested control 35 days after planting. Least significant difference $=0.13 \mathrm{~g}(P=0.05)$.

and root dry weights (Table 2). Reduction in shoot and root dry weights of plants grown in noninfested soil:sand mixtures occurred, but no root discoloration was observed. Longer periods of saturation duration caused lower shoot and root dry weights, as did lower soil water content (increased sand content of soil:sand mixtures) (Figs. 3 and 4). The one exception to this trend was that isolate 201-25 caused significantly lower shoot and root weights in the soil:sand mixture containing $20 \%$ sand than in $100 \%$ sand (Figs. 3 and 4). Intercepts of regression lines were lower for all inoculated treatments than for the controls (Table 2).

Slope values for saturation duration and soil water content were less negative for isolates than for the noninfested control. The lower slope values $\left(b_{1}\right.$ and $\left.b_{2}\right)$ obtained in inoculated treatments indicated that longer saturation durations and lower soil water content caused less change in shoot and root dry weight in comparison with the non-inoculated controls. Additionally, the lower intercepts in inoculated treatments than in the non-inoculated controls indicated that the presence of the pathogen reduced root/shoot weights for all saturation durations and soil water contents (Figs. 3 and 4). In general, $R^{2}$ values were higher for regression equations for individual experiments than for data combined across experiments (Table 2). There was a significant $(P=0001)$ positive correlation between shoot and root dry weight, but the correlation coefficient was low $(r=0.19)$.

\section{DISCUSSION}

A range in aggressiveness was detected among 15 field isolates of $P$. arrhenomanes from maize. Deep and Lipps (7) reported similar differences among isolates from maize; Hoy et al. (16) reported differences among isolates from sugarcane; and Rands (29) reported differences among isolates from both maize and sugarcane.

Several isolates capable of inciting high levels of disease under the conditions of these tests were used to evaluate the effect of flooding duration and soil water content on maize root rot. Maize growth was proportional to the duration of soil saturation and soil water content without the presence of $P$. arrhenomanes and with each of the three isolates tested. Root and shoot weights were significantly lower in infested soil:sand mixtures than in the noninfested controls for each of the five saturation durations. When soil matric potential was maintained at/or above $-1 \mathrm{~J} / \mathrm{kg}$, maize plants grown in infested soil:sand mixtures had significantly lower shoot and root dry weights than plants grown in noninfested controls. Apparently, soil saturation was not necessary for infection and disease development, but plants were more negatively affected when saturated conditions existed for an extended period of time because of the additive effect of the pathogen and soil water on plant growth.

The soil:sand mixtures used in these tests provided a range of soil water contents. At saturation the 0:100 soil:sand mix had only half the amount of water of the 100:0 mix (19.4 $\mathrm{g}$ and $38.3 \mathrm{~g}$ water per 100 $\mathrm{g}$ soil:sand mix, respectively). Maize plants were more adversely affected by root rot when grown in soil:sand mixtures with less water content. The influence of $100 \%$ sand may have been due to the greater number of large pore spaces suitable to accommodate zoospore movement $(10,28)$ or to more root surface in direct 
Table 2. Multiple regression statistics describing the relationship between flooding duration and soil water content, as percentage of sand in soil:sand mixtures, and their effect on shoot and root dry weight of maize inoculated with three isolates of Pythium arrhenomanes

\begin{tabular}{|c|c|c|c|c|c|c|c|}
\hline \multirow[b]{2}{*}{ Isolate } & \multirow[b]{2}{*}{ Experiment } & \multicolumn{3}{|c|}{ Partial regression coefficients } & \multirow[b]{2}{*}{$R^{2}$} & \multirow[b]{2}{*}{$\mathbf{d f}^{\mathbf{a}}$} & \multirow[b]{2}{*}{ Error MS } \\
\hline & & Intercept & Flooding duration & Percent sand & & & \\
\hline \multicolumn{8}{|c|}{ Shoot dry weight (g) } \\
\hline $7 \mathrm{E}$ & $\begin{array}{l}1 \\
2 \\
3 \\
\text { Combined }\end{array}$ & $\begin{array}{l}0.43(0.014)^{\mathrm{b}} \\
1.26(0.028) \\
1.48(0.041) \\
1.06(0.042)\end{array}$ & $\begin{array}{l}-0.004(0.0005) \\
-0.012(0.0010) \\
-0.014(0.0015) \\
-0.011(0.0016)\end{array}$ & $\begin{array}{l}-0.077(0.019) \\
-0.350(0.039) \\
-0.675(0.057) \\
-0.367(0.059)\end{array}$ & $\begin{array}{l}0.52 \\
0.74 \\
0.74 \\
0.25\end{array}$ & $\begin{array}{r}77 \\
77 \\
77 \\
237\end{array}$ & $\begin{array}{l}0.004 \\
0.017 \\
0.037 \\
0.118\end{array}$ \\
\hline $201-25$ & $\begin{array}{l}1 \\
2 \\
3 \\
\text { Combined }\end{array}$ & $\begin{array}{l}0.49(0.023) \\
1.55(0.080) \\
1.80(0.108) \\
1.28(0.065)\end{array}$ & $\begin{array}{l}-0.006(0.0009) \\
-0.012(0.0030) \\
-0.019(0.0040) \\
-0.012(0.0024)\end{array}$ & $\begin{array}{l}-0.043(0.032) \\
-0.804(0.112) \\
-0.695(0.151) \\
-0.514(0.090)\end{array}$ & $\begin{array}{l}0.38 \\
0.47 \\
0.36 \\
0.20\end{array}$ & $\begin{array}{r}77 \\
77 \\
77 \\
237\end{array}$ & $\begin{array}{l}0.118 \\
0.143 \\
0.258 \\
0.278\end{array}$ \\
\hline $5 \mathrm{E}$ & $\begin{array}{l}1 \\
2 \\
3 \\
\text { Combined }\end{array}$ & $\begin{array}{l}0.29(0.013) \\
1.75(0.035) \\
1.28(0.051) \\
1.11(0.058)\end{array}$ & $\begin{array}{l}-0.003(0.0005) \\
-0.012(0.0013) \\
-0.015(0.0019) \\
-0.010(0.0021)\end{array}$ & $\begin{array}{l}-0.045(0.018) \\
-0.856(0.050) \\
-0.284(0.071) \\
-0.340(0.081)\end{array}$ & $\begin{array}{l}0.33 \\
0.83 \\
0.52 \\
0.16\end{array}$ & $\begin{array}{r}77 \\
77 \\
77 \\
237\end{array}$ & $\begin{array}{l}0.004 \\
0.028 \\
0.057 \\
0.221\end{array}$ \\
\hline Control & $\begin{array}{l}1 \\
2 \\
3 \\
\text { Combined }\end{array}$ & $\begin{array}{l}2.05(0.050) \\
3.05(0.080) \\
3.67(0.067) \\
2.93(0.069)\end{array}$ & $\begin{array}{l}-0.015(0.0019) \\
-0.025(0.0029) \\
-0.024(0.0025) \\
-0.021(0.0026)\end{array}$ & $\begin{array}{l}-0.622(0.070) \\
-1.639(0.111) \\
-1.634(0.094) \\
-1.298(0.097)\end{array}$ & $\begin{array}{l}0.65 \\
0.79 \\
0.84 \\
0.51\end{array}$ & $\begin{array}{r}77 \\
77 \\
77 \\
237\end{array}$ & $\begin{array}{l}0.056 \\
0.140 \\
0.101 \\
0.319\end{array}$ \\
\hline \multicolumn{8}{|c|}{ Root dry weight (g) } \\
\hline $7 \mathrm{E}$ & $\begin{array}{l}1 \\
2 \\
3 \\
\text { Combined }\end{array}$ & $\begin{array}{l}0.19(0.007) \\
0.68(0.018) \\
0.89(0.027) \\
0.58(0.027)\end{array}$ & $\begin{array}{l}-0.002(0.0003) \\
-0.007(0.0007) \\
-0.009(0.0010) \\
-0.006(0.0010)\end{array}$ & $\begin{array}{l}-0.001(0.011) \\
-0.221(0.026) \\
-0.359(0.037) \\
-0.194(0.038)\end{array}$ & $\begin{array}{l}0.39 \\
0.68 \\
0.69 \\
0.20\end{array}$ & $\begin{array}{r}77 \\
77 \\
77 \\
237\end{array}$ & $\begin{array}{l}0.001 \\
0.008 \\
0.016 \\
0.048\end{array}$ \\
\hline $201-25$ & $\begin{array}{l}1 \\
2 \\
3 \\
\text { Combined }\end{array}$ & $\begin{array}{l}0.20(0.010) \\
0.76(0.036) \\
0.95(0.058) \\
0.63(0.035)\end{array}$ & $\begin{array}{l}-0.003(0.0004) \\
-0.007(0.0013) \\
-0.010(0.0021) \\
-0.007(0.0013)\end{array}$ & $\begin{array}{l}-0.009(0.014) \\
-0.283(0.051) \\
-0.311(0.081) \\
-0.201(0.050)\end{array}$ & $\begin{array}{l}0.47 \\
0.43 \\
0.32 \\
0.15\end{array}$ & $\begin{array}{r}77 \\
77 \\
77 \\
237\end{array}$ & $\begin{array}{l}0.002 \\
0.029 \\
0.074 \\
0.084\end{array}$ \\
\hline $5 \mathrm{E}$ & $\begin{array}{l}1 \\
2 \\
3 \\
\text { Combined }\end{array}$ & $\begin{array}{l}0.22(0.008) \\
0.88(0.021) \\
0.70(0.028) \\
0.60(0.028)\end{array}$ & $\begin{array}{l}-0.002(0.0003) \\
-0.008(0.0008) \\
-0.008(0.0011) \\
-0.006(0.0010)\end{array}$ & $\begin{array}{l}-0.051(0.011) \\
-0.350(0.029) \\
-0.104(0.040) \\
-0.168(0.040)\end{array}$ & $\begin{array}{l}0.48 \\
0.76 \\
0.43 \\
0.18\end{array}$ & $\begin{array}{r}77 \\
77 \\
77 \\
237\end{array}$ & $\begin{array}{l}0.001 \\
0.009 \\
0.018 \\
0.051\end{array}$ \\
\hline Control & $\begin{array}{l}1 \\
2 \\
3 \\
\text { Combined }\end{array}$ & $\begin{array}{l}0.55(0.016) \\
1.31(0.036) \\
1.83(0.040) \\
1.23(0.049)\end{array}$ & $\begin{array}{l}-0.004(0.0006) \\
-0.010(0.0013) \\
-0.016(0.0015) \\
-0.010(0.0018)\end{array}$ & $\begin{array}{l}-0.082(0.023) \\
-0.445(0.051) \\
-0.624(0.056) \\
-0.384(0.069)\end{array}$ & $\begin{array}{l}0.44 \\
0.63 \\
0.75 \\
0.20\end{array}$ & $\begin{array}{r}77 \\
77 \\
77 \\
237\end{array}$ & $\begin{array}{l}0.006 \\
0.029 \\
0.036 \\
0.163\end{array}$ \\
\hline
\end{tabular}

a df $=$ degrees of freedom.

$\mathrm{b}$ The value in parentheses represents the standard deviation of the estimate.

contact with water films. In any case, the effect of soil water content on maize root rot could be due to conditions that favor pathogen activity as well as factors that predispose the plant to infection $(1,5,6$, 25,26,27).

In northwest Ohio, where maize is grown in heavy clay soils like the Hoytville silty-clay loam used in this study, water drains more slowly from the soil profile following a heavy rain than locations with more sandy soil textures. Maize growth is adversely affected under these conditions as a result of root rot caused by $P$. arrhenomanes and protracted periods of soil saturation in heavy clay soils (7). It may be possible to increase the growth of maize in heavy clay soil by managing soil water through improved drainage by tiling, tillage, or a combination of both.

\section{ACKNOWLEDGMENTS}

Salaries and research support provided by State and Federal funds appropriated to the Ohio Agricultural Research and Development Center, The Ohio State University, and by Gazi Osman Pasa University, Tokat, Turkey. Manuscript number 100-95.

\section{LITERATURE CITED}

1. Allmoras, R. R., Kraft, J. M., and Miller, D. E. 1988. Effects of soil compaction and incorporated crop residue on root health. Annu. Rev. Phytopathol. 26:219- 243.

2. Anonymous. 1990. 1990 National Survey of Conservation Tillage Practices. Conservation Tillage Information Center, West Lafayette, IN.

3. Bowers, J. H., and Mitchell, D. J. 1990. Effect of soil water matric potential and periodic flooding on mortality of pepper caused by Phytophthora capsici. Phytopathology 80:1447-1450.

4. Brown, G. E., and Kennedy, B. W. 1966. Effect of oxygen concentration on Pythium seed rot of soybean. Phytopathology 56:407411.

5. Browne, G. T., and Mircetich, J. M. 1988. Effect of flood duration on the development of Phytophthora root and crown rots of apple. Phytopathology. 78:846-851.

6. Carpenter, C. W. 1934. Predisposing factors in Pythium root rot. Hawaii. Plant Res. 38: 279338.

7. Deep, I. W. and Lipps, P. E. 1996. Recovery of Pythium arrhenomanes and its virulence to corn. Crop Prot. 15:85-90.

8. Dick, W. A., and VanDoren, D. M., Jr. 1985. Continuous tillage and rotation combinations effects on corn, soybean, and oat yields. Agron. J. 77:459-465.

9. Drechsler, C. 1928. Pythium arrhenomanes n. sp. parasite causing maize root rot. Phytopathology 18:873-875.

10. Duniway, J. M. 1976. Movement of zoospores of Phytophthora cryptogea in soil of various textures and matric potentials. Phytopathology 66:877-882.

11. Duniway, J. M. 1979. Water relations of water molds. Annu. Rev. Phytopathol. 17:431-460.

12. Griffin, D. M. 1963. Soil physical factors and the ecology of fungi, behavior of Pythium ultimum at small soil water suctions. Trans. Br. Mycol. Soc. 46:368-372.

13. Griffith, D. R., Mannering, J. V., Galloway, H. M., Parsons, S. D., and Richey, C. B. 1973. Effect of eight tillage planting systems on soil temperature, percent stand, plant growth, and yield of corn on five Indiana soils. Agron. J. 65:418-428.

14. Hampton, R. O., and Buchholt, W. F. 1959. Seasonal occurrence of Pythium graminicola on roots of field grown corn. Iowa State Coll. J. Sci. 33:489-495.

15. Hord, M. J., and Ristaino, J. B. 1992. Effect of matric component of soil water potential on infection of pepper seedlings in soil infested with oospores of Phytophthora capsici. Phytopathology 82:792-798.

16. Hoy, J. W., and Schneider, R. W. 1988. Role of Pythium in sugarcane stubble decline: Pathogenicity and virulence of Pythium species. Phytopathology 78:1688-1692.

17. Johann, H., Holbert, J. R., and Dickson, J. G. 1928. A Pythium seedling blight and root rot 
of dent corn. J. Agric. Res. 37:443-464.

18. Johnson, J., and Hartman, R. E. 1919. Influence of soil environment on the root rot of tobacco. J. Agric. Res.17:41-86.

19. Kenerly, C. M., Papke, K., and Bruck, R. I. 1984. Effect of flooding on development of Phytophthora root rot of Fraser Fir seedlings. Phytopathology 74:401-404.

20. Lipps, P. E. 1980. The influence of temperature and water potential on asexual reproduction by Pythium spp. associated with snow rot of wheat. Phytopathology 70:794-797.

21. Lipps, P. E. and Deep, I. W. 1991. Influence of tillage and crop rotation on yield, stalk rot, and recovery of Fusarium and Trichoderma spp. from corn. Plant Dis. 25:828-833.

22. MacDonald, J. D., and Duniway, J. M. 1978. Influence of the matric and osmotic components of water potential on zoospores of Phytophthora. Phytopathology 68:751-757.

23. Matheron, M. E., and Mircetich, J. M. 1985. Influence of flooding duration on development of Phytophthora root and crown rot of Juglans hindsii and Paradox walnut rootstocks. Phytopathology 75:973-976.

24. McKeen, W. E. 1951. A preliminary study of corn seedling blight in Southern Ontario. Can. J. Agric. Res. 49:189-121.

25. Miller, D. E., and Burke, D. W. 1975. Effect of soil aeration on Fusarium root rot of beans. Phytopathology 65:519-523.

26. Miller, D. E., and Burke, D. W. 1977. Effect of temporary excessive wetting on soil aeration and Fusarium root rot of beans. Plant Dis. Rep. 61:175-179.

27. Ohmura, T., and Howell, R. W. 1960. Inhibitory effect of water on oxygen consumption by plant materials. Plant Physiol. 35:184-188.

28. Pfender, W. F., Hine, R. B., and Stanghellini, M. E. 1977. Production of sporangia and release of zoospores by Phytophthora megasperma in soil. Phytopathology 67:657-663.

29. Rands, R. D. 1934. Variability in Pythium arrhenomanes in relation to root rot of sugarcane and corn. J. Agric. Res. 49:189-221.

30. Rao, B., Schmitthenner, A. F., Caldwell, R., and Ellett, C. W. 1978. Prevalence and virulence of Pythium species associated with root rot of corn in poorly drained soil. Phytopathology 68:1557-1563.

31. Schmitthenner, A. F. 1974. Isolation and identification methods for Phytophthora and Pythium. Proc. First Woody Ornamental Dis- ease Workshop, University of Missouri, Columbia.

32. Side de bottom, J. R., and Shem, H. D. 1985 Effects of soil texture and matric potential on sporangium production by Phytophthora parasitica var. nicotianae. Phytopathology 75:1435-1438.

33. Stanghellini, M. E. 1974. Spore germination, growth and survival of Pythium in soil. Proc. Am. Phytopathol. Soc. 1:211-214.

34. Stanghellini, M. E., and Burr, T. J. 1973 Germination in vivo of Pythium aphanidermatum oospores and sporangia. Phytopathology 63:1493-1496.

35. VanDoren, D. J., Triplett, Jr., and Henry, J. E. 1976. Influence of long term tillage, crop rotation and soil type combinations on corn yield. Soil Soc. Am. J. 40:100-105.

36. Wilcox, W. F., and Mircetich, J. M. 1985. Effect of flooding duration on the development of Phytophthora root and crown rots of Cherry. Phytopathology 75:1451-1455.

37. Wilcox, W. F., and Mircetich, J. M. 1985 Influence of soil water matric potential on the development of Phytophthora root and crown rots of Mahaleb Cherry. Phytopathology 75:648-653. 